Received, 30 October 2018, Accepted, 5 May 2019

Link to DOI:

10.25220/WNJ.V03.i1.0002 Journal Website: www.worldnutrijournal.org

\section{Comparing The Anthropometric Measurements of Intra-Extra Uterine Period between Stunting and Non-stunting Children Aged 6-24 Months Old in Bogor Tengah Sub District, Bogor City, West Java}

Christina Olly Lada ${ }^{1,3}$, Jose Rizal Batubara ${ }^{1}$, Saptawati Bardosono, ${ }^{1}$ Anies Irawati, ${ }^{2}$ Salimar ${ }^{2}$

1. Department of Nutrition, Faculty of Medicine, Universitas Indonesia, Cipto Mangunkusumo General Hospital, Jakarta, Indonesia

2. National Health Research and Development

3. Department of Nutrition, Faculty of Medicine, Nusa Cendana University, Kupang, Indonesia

\begin{abstract}
Introduction Stunting in 6-24 months old children has many negative health consequences in later life. However, stunting could be detected earlier by using anthropometry indicators. This study aims to compare the anthropometry of the intrauterine and extra uterine period between stunting and non-stunting children aged 6-24 months.

Methods This comparative cross-sectional study was part of Bogor longitudinal study on child growth and development (BLSCGD) held by National Health Research and Development (NHRD), Indonesia. Inclusion criteria were children aged 6-24 months, born full term from single pregnancy (not twins) and had $>24$ months age difference with previous sibling. Subjects with birth defect were excluded. Data were collected by measuring anthropometric sizes using WHO standard. Primary and secondary data collection was done from July 2017 to February 2018 at the BLSCGD. Statistical analysis was used to compare anthropometric sizes between stunting and non-stunting groups ( $p$ value $<0.05$ ).

Results There were 38 stunting and 46 non-stunting children who met the study criteria. Maternal height $(p<0.001)$, birth weight $(p=0.009)$ and length $(p=0.025)$ were significantly lower in stunting group compared to non-stunting group. Extra uterine factors such as weight gain at six months of age $(p=0.002)$, neonatal weight gains per month in the first six months $(p=0.002)$, increase of body length in age six months old $(p<0.001)$, body length gains per month in the first six months $(p<0.001)$ were significantly lower in stunting children.

Conclusion The anthropometrics of stunting children during intrauterine and extra uterine period was significantly lower compared to non-stunting. It is essential to monitor the anthropometry of intra-extra uterine period to prevent stunting at age 6-24 months old.
\end{abstract}

Keywords stunting, intrauterine, extra uterine factors

Corresponding author:

Christina Olly Lada

Nutrition Department, Medical Faculty of

Universitas Indonesia, Jakarta, Indonesia

Email: Christina_o_l@yahoo.com 


\section{Introduction}

Children grow rapidly in the first 1000 days and have high nutrition requirements. There are many challenges to fulfill their nutritional needs, especially during under two years old of age. ${ }^{1}$ The cause of stunting in age under two years old is an imbalance of requirement and intake in a prolonged period. $^{2}$ The low intake of food, infection, the transition period from exclusive breast feeding to weaning of complementary food commonly occur in children aged less than two years old. ${ }^{3,4}$ Meanwhile, studies showed that maternal stature is one of the many factors that influenced height for age z-score (HAZ) in early life. ${ }^{5-7}$

Intra and extra uterine factors can cause stunting. Maternal chronic nutritional deficiencies from conception until birth is an intrauterine factor. This causes small fetus size shown by low birth weight or short birth length. ${ }^{8}$ This can be measured with intrauterine anthropometry which consists of maternal height, maternal body mass index before pregnancy, weight gain during pregnancy, baby birth weight and length. Extra uterine factors are formed from birth to six months of age. After six months old, infants should receive complementary foods. ${ }^{9-11}$ At age 12-23 months old, the fulfillment of daily energy needs from breast feeding is 35$40 \%$ and $60-65 \%$ is from complementary foods. ${ }^{12}$ Indicators of extra uterine anthropometry are weight gain and increase of body length at six months old, monthly body weight, length gain and arm circumference profile from birth until six months old.

Stunting is a preventable condition. Finding an early curable risk factor will reduce stunting prevalence in children aged up to two years old. This study aimed to compare the anthropometry measurements of intra and extra uterine period between stunting and non-stunting children aged 624 months.

\section{Methods}

The design of this study was comparative crosssectional nested to BLSCGD in order to obtain data on the child's and mother's medical history during pregnancy and data on the child's growth from birth until aged six months. The BLSCGD research was done by the NHRD, Ministry of Health research team in the District of Bogor Tengah, City of Bogor from 2012 to 2032 . The data collection was done from July 2017 until February 2018 at the Health Research and Development Center Community Health Efforts, Ministry of Health, Bogor, West Java.

The estimated numbers of subject calculated was 162 children. Subjects were divided into two groups namely stunting group (81 children) and non-stunting group (81 children). Consecutive sampling was used to select the subjects and standardized questionnaire was used for subject screening. Inclusion criteria were children 6-24 months old who were registered member of BLSCGD, born from full-term, single pregnancy, had age difference $>24$ months with the previous sibling and the mother's age more than 20 years old when pregnant with the subject. Lastly, all subjects' mothers have agreed and signed informed consent to participate in this research. Subjects were excluded if they have birth defect.

Subjects were defined as stunting if their height for age $\mathrm{Z}$-score was more than two standard deviations below the WHO Child Growth standards median. This research was approved by the Ethical Committee for Research in Human from the Faculty of Medicine, Universitas Indonesia (No. 540/UN2.F1/ETIK/2017) and by Director of NHRD of Health Ministry of Republic Indonesia. (No. LB.01.03/1/3471/2017).

Primary data collected were child identity, birth date and body length. Secondary data, using a standardized form, were collected from BLSCGD as follows: (1)to identify intrauterine anthropometric factors: mother's height and weight before and while pregnant, mother's monthly weight gain while pregnant, subject's birth weight and length, (2)to identify extra uterine anthropometric factors: subject's weight and length gains at first six months of age, mean of monthly weight and length gains at first six months of age, arm circumference at age one week, arm circumference gain at first six months of age, mean of monthly increase of arm circumference at first 
six months of age. All of the measurement meets the WHO standards.

The data was then analyzed by the SPSS version 20 program. The normality of variables was tested using a Kolmogorov-Smirnov test. Classification and a correlation between variables were analyzed using a Spearman or Pearson test or independent T-test.

\section{Results}

During data collection one subject was excluded due to having cleft palate, one subject excluded due to born as twins and several others did not agree to participate in this study. Hence the total numbers of subject collected were 84 children. The selected children were grouped into stunting and non- stunting. Subject characteristics were are shown in Table 1.

As seen in Table 1, there was no significance of data difference between stunting and non-stunting group.

Intrauterine predisposing factors are presented in Table 2, which describes differences in maternal anthropometry size before and during pregnancy and the size of newborns. Maternal height before pregnancy, birth weight, and birth length were significantly lower in stunting children compared to non-stunting children.

As expected, the numbers of mother with short stature are more significant in stunting group. Numbers of subjects who had birth weight less than 3 kilograms and short birth length are also more significant in stunting group.

Table 1. Subject baseline characteristics

\begin{tabular}{|c|c|c|c|}
\hline Variable & Stunting $(\mathrm{n}=38)$ & Non-stunting $(\mathrm{n}=46)$ & $\mathrm{p}$ value \\
\hline Age (month) & $16.3 \pm 5.3$ & $16.1 \pm 5.1$ & $0.888^{\mathrm{TT}}$ \\
\hline \multicolumn{4}{|l|}{ Gender $(\mathrm{n}, \%)$} \\
\hline Boy & $17(44.7)$ & $22(47.8)$ & \\
\hline Girl & $21(55.3)$ & $24(52.2)$ & $0.778^{\mathrm{CS}}$ \\
\hline Mother's age (years) & $28 \pm 5.7$ & $29.1 \pm 5.4$ & $0.567^{\mathrm{TT}}$ \\
\hline \multicolumn{4}{|l|}{ Mother's educational level (n,\%) } \\
\hline Did not attend school & $1(2.6)$ & - & \\
\hline Did not graduate elementary & - & - & \\
\hline Elementary graduated & $8(21.1)$ & $5(10.9)$ & \\
\hline Junior high graduated & $9(23.7)$ & $15(32.6)$ & \\
\hline Senior high graduated & $17(44.7)$ & $22(47.8)$ & \\
\hline University graduated & $3(7.9)$ & $4(8.7)$ & $0.884^{\mathrm{KS}}$ \\
\hline \multicolumn{4}{|l|}{ Occupation $(\mathrm{n}, \%)$} \\
\hline Unemployed & - & $1(2.2)$ & \\
\hline Government officials & $3(7.9)$ & $3(6.5)$ & \\
\hline Entrepreneur & - & $2(6.5)$ & \\
\hline Farmer/laborer/fisherman & - & $4(8.7)$ & \\
\hline Housewive & $35(92.1)$ & $36(78.3)$ & $0.871^{\mathrm{KS}}$ \\
\hline
\end{tabular}


Table 2 Anthropometric measurement differences between stunting and non stunting group

\begin{tabular}{|c|c|c|c|}
\hline Anthropometric measurements & Stunting $(\mathrm{n}=38)$ & $\begin{array}{l}\text { Non stunting } \\
(\mathrm{n}=46)\end{array}$ & $\mathrm{p}$-value \\
\hline Mother's height $(\mathrm{cm})$ & $148.8 \pm 4.9$ & $154.0 \pm 4.5$ & $<\mathbf{0 . 0 0 1} 1^{\mathrm{TT}}$ \\
\hline Short stature $<150$ & $21(55.3)$ & $9(19.6)$ & \\
\hline Normal stature $\geq 150$ & $17(44.7)$ & $37(80.4)$ & $\mathbf{0 . 0 0 1}{ }^{\mathrm{CS}}$ \\
\hline Mother's BMI before pregnancy $\left(\mathrm{kg} / \mathrm{m}^{2}\right)$ & $22.5 \pm 4.3$ & $22.9 \pm 3.9$ & $0.631^{\mathrm{TT}}$ \\
\hline Underweight $<18.5$ & $5(13.2)$ & $4(8.7)$ & \\
\hline Normal 18.5-24.9 & $24(63.2)$ & $31(67.4)$ & \\
\hline Overweight /Obese $\geq 25$ & $9(23.6)$ & $11(23.9)$ & $0.802^{\mathrm{LR}}$ \\
\hline Maternal weight gain $(\mathrm{kg})$ & $10.1 \pm 5.6$ & $12.2 \pm 6.7$ & $0.137^{\mathrm{TT}}$ \\
\hline Less $(<11.5)$ & $25(65.8)$ & $21(45.7)$ & \\
\hline Appropriate (11.5-16) & $7(18.4)$ & $16(34.8)$ & \\
\hline More (16) & $6(15.8)$ & $9(19.6)$ & $0.154^{\mathrm{CS}}$ \\
\hline Subject's birth weight $(\mathrm{kg})$ & $2.9 \pm 0.2$ & $3.1(2.5-4.5)$ & $\mathbf{0 . 0 0 9} 9^{\mathrm{MW}}$ \\
\hline LBW $<2.5$ & $1(2.6)$ & - & \\
\hline Normal 2.5-2.9 & $15(39.5)$ & $9(19.6)$ & \\
\hline Ideal $\geq 3$ & $22(57.9)$ & $37(80.4)$ & $\mathbf{0 . 0 1 9} 9^{\text {LLA }}$ \\
\hline Subject's birth length $(\mathrm{cm})$ & $47(45-50)$ & $48.8 \pm 2.1$ & $\mathbf{0 . 0 2 5} 5^{\mathrm{MW}}$ \\
\hline Short $<48$ & $22(57.9)$ & $21(45.7)$ & \\
\hline Normal $\geq 48$ & $16(42.1)$ & $25(54.3)$ & $0.269^{\mathrm{TT}}$ \\
\hline
\end{tabular}

Table 3. The differences of anthropometry between stunting and non stunting subjects

\begin{tabular}{lccc}
\hline Variables & Stunting (n=38) & Non-stunting (n=46) & p-value \\
\hline Weight gain aged six months (kg) & $3.6 \pm 0.7$ & $4.2 \pm 0.9$ & $\mathbf{0 . 0 0 2}^{\mathrm{TT}}$ \\
$\begin{array}{l}\text { Weight gain per month at first six months } \\
\text { after born (kg) }\end{array}$ & $0.6 \pm 0.1$ & $0.7 \pm 0.1$ & $\mathbf{0 . 0 0 2}^{\mathrm{TT}}$ \\
$\begin{array}{l}\text { Length increase aged six months (cm) } \\
\text { Length increase per month at first six months } \\
\text { after born (cm) }\end{array}$ & $14.1 \pm 2.3$ & $16.0 \pm 2.1$ & $\mathbf{0 . 0 0 1}^{\mathrm{TT}}$ \\
$\begin{array}{l}\text { Birth arm circumference/AC (cm) } \\
\text { Increase of AC aged six months (cm) }\end{array}$ & $2.3 \pm 0.4$ & $10.9(7.0-12.4)$ & $0.266^{\mathrm{MW}}$ \\
$\begin{array}{l}\text { Increase of AC per months at first six months } \\
\text { after born (cm) }\end{array}$ & $10.0(8.3-12.7)$ & $3.5 \pm 1.4$ & $0.751^{\mathrm{TT}}$ \\
\hline
\end{tabular}

${ }^{\mathrm{MW}}$ Mann Whitney, ${ }^{\mathrm{TT}}$ Unpaired T-test, ${ }^{\mathrm{CS}}$ Chi-square, AC: Arm Circumference

Extra uterine predisposing factors, which describe differences of anthropometric measurements between subjects with stunting and non stunting, are shown in Table 3.
The increase of body weight and length during the first six months, and also monthly weight and length gain were significantly smaller in stunting than non-stunting children. 


\section{Discussion}

In this study subjects in both groups had similar characteristics of mother's age, subject's age and gender. There was no significant difference in parent's educational background and job between both groups. Educational background overview shows there are still parents who never attended school or completed elementary school education. Data from Center of Statistic Bogor City in 2017 shows in general Bogor city residents work in trading and services sector with junior and senior high school as most common educational background. ${ }^{13}$ Almost all biological mothers from 84 subjects are housewives and are high school graduated. Parent's educational background and job showed that the subjects came from middle to lower economic class families. Stunting children under five years of age generally came from middle to lower class families. ${ }^{2,14}$

Table 2 shows that maternal height before pregnancy, birth weight, and birth length were significantly lower in stunting compared to nonstunting children. Correspondingly, the proportions of mothers short stature, subject's birth weight less than three kilograms and body length $<46 \mathrm{~cm}$ are still more significant in stunting children.

This study showed that maternal height before pregnancy and intra uterine fetal growth are essential factors for the incidence of stunting in children aged 6-24 months. The result of this research is in line with the meta-analysis study by Addo et al. ${ }^{15}$ It was done in five cohort studies in Brazil, India, Guatemala, the Philippines, and South Africa with a total sample of 7,630 pregnant women. Observations were done from pregnancy to delivery until the children were two years old, less than seven years old and adulthood. The study found that maternal height was positively related to birth weight and childbirth: mothers with height less than $150.1 \mathrm{~cm}$ had 3.2 times more risk to birth children who will be stunted at 2 years of age compared to those with height more than or equal to $150.1 \mathrm{~cm}^{15}$

A retrospective study involved 412 children in Guatemala found that there was a significant positive relationship between maternal height and body length for age $\mathrm{z}$ scores of infants aged 6 and 12 months old. ${ }^{16}$ Short statured mothers were more likely to have stunting children because the phenotype for stunted growth would be passed on to the next generation. ${ }^{7}$ A research by Lestari et a $1^{17}$ on 110 stunting and non-stunting children aged 624 months old in Aceh found the most dominant risk factor for the incidence of stunting in early life (children aged 6-24 months) was maternal or paternal short stature. Consistent with this research, a hospital-based study in Japan by Inoue et al. ${ }^{18}$ found that a significant relationship between short maternal stature with low birth weight in 17.150 pairs of Japanese mothers and newborns.

The newborn baby with low birth weight or low birth length become stunting at 6-24 months. This result corresponds with literature study which suggests that maternal height contributes to birth weight, and birth weight contributes to incidence of stunting in children under two years old. ${ }^{5}$ Short statured mothers have higher risk to birth children with low birth weight. ${ }^{2}$ The pathophysiology of relationship between babies with low birth weight and birth length born from mother with short stature is still unclear. However, some researchers speculate that fetal growth patterns are imprinted by maternal short stature phenotypes, thus their offspring adapt to subsequent growth patterns, known as intergenerational effect. ${ }^{19-21}$

Although not significantly different, the mean maternal weight gain during pregnancy in stunting group was $2.1 \mathrm{~kg}$ lower than non-stunting group. Moreover, $65.8 \%$ mothers of stunting children had history of less than $11.5 \mathrm{~kg}$ weight gain from early until late pregnancy. Weight gain during pregnancy describes the nutritional adequacy of pregnant women and indirectly describes intra uterine fetal growth. Irawati and Rachmalina's $\mathrm{s}^{22}$ research on 94 pregnant women in Bogor concluded that the maternal body mass index before pregnancy was the most influential risk factor for maternal weight gain during pregnancy. The causes of the low birth weight and length in this study was unknown because this study did not evaluate the food intake of pregnant women and maternal physical activity during pregnancy.

Changes in growth patterns presented in Table 3 show that weight gain and body length in 
the first six months of extra uterine life of stunting children were significantly smaller compared to non-stunting children, so do the average weight gain and body length in the first six months. At 3 months old until around 12-18 months old babies grow rapidly. ${ }^{23}$ The weight gain in the first six months and the average monthly weight gain in a stunting child are less than non-stunting children. Stunting children should get more attention from their mothers in food intake and infection control in order to catch up with growth. The complete monthly weight and length data obtained in this study may indicate that the mothers are diligent in monitoring monthly children growth. However, they need to be given knowledge and skills to overcome problems about slow growth rate in children. $^{24}$

The average monthly increase of child body length in stunting and non stunting group were 2.3 $\mathrm{cm}$ and $2.7 \mathrm{~cm}$, respectively. The children growth rate in up to one-year-old is approximately 25 $\mathrm{cm} /$ year, then the linear growth rate will decrease to around $10 \mathrm{~cm} /$ year starting at 4 years old. In other words children's linear growth rate at age 624 months old is around $0.8-2 \mathrm{~cm} /$ month. $^{23}$ The results of this study shows that the children's linear growth rates were still relatively healthy.

There are several limitations to this study. First, this study did not provide maternal intake during pregnancy, neonatal intake history (breastfeeding or food). Secondly, subject's activities was not collected, thus the balance of nutritional demand in intrauterine and extra uterine period could not be evaluated.

In conclusion, intrauterine and extra uterine predisposing anthropometric characteristics of stunting children aged 6-24 months old are short mother's stature, low birth weight, low birth length, less weight gain in the first six months, low monthly weight gain in the first six months, low body length for the first six months, less monthly increase in body length in the first six months.

The significant intrauterine predisposition factors of stunting children are mothers' anthropometric status before and while pregnant. It was shown that mother's height, which represented mother's nutrition pool before pregnancy, was an essential factor of fetal development. Recent studies are consistent with this result, even though intervention studies in pregnant woman did not show improvement of fetal development, weight or height. Monitoring height of adolescent girls will prevent short maternal stature. Also, routine anthropometric measurements of mothers during pregnancy and babies in the first six months old would prevent stunting at age 6-24 months old.

\section{Conflict of Interest}

There was no conflict of interest regarding this study

\section{Open Access}

This article is distributed under the terms of the Creative Commons Attribution 4.0 International Licence(http://creativecommons.org/licenses/by/4.0 /), which permits unrestricted use, distribution, and reproduction in any medium, provided you give appropriate credit to the original author(s) and the source, provide a link to the Creative Commons license, and indicate if changes were made.

\section{References}

1. Dewey KG, Begum K. Long-term consequences of stunting in early life. Matern Child Nutr. 2011;7:5-18.

2. Prendergast AJ, Humphrey JH. Stunting syndrome in developing countries. Paediatrics and International Child Health. 2014; 34:250265

3. Mal-ED Network Investigators. Childhood stunting in relation to the pre- and postnatal environment during the first 2 years of life: The MAL-ED longitudinal birth cohort study. PLoS Med 2017;14:1-21.

4. Badham J, Sweet L. Stunting: an overview. Sight Life 2010;3:40-7.

5. Martorell R, Zongrone A. Intergenerational influences on child growth and undernutrition. Paediatr Perinat Epidemiol 2012;26:302-14.

6. Tebeje NB, Bikes GA, Abebe SM, Yesuf ME. Prevalence and major contributors of child malnutrition in developing countries: systematic review and meta-analysis. J Child Obes [Internet] 2017;02:1-7

7. Ozaltin E, Hill K, Subramanian S V. Association of maternal stature with offspring mortality, 
underweight, and stunting in low- to middleincome countries. JAMA 2010;303:1507-16.

8. Abu-Saad K, Fraser D. Maternal nutrition and birth outcomes. Epidemiol Rev 2010;32:5-25.

9. Robinson S, Fall C. Infant nutrition and later health: A review of current evidence. Nutrients 2012;4:859-74.

10. Ferré P, Decaux JF, Issad T, Girard J. Changes in energy metabolism during the suckling and weaning period in the newborn. Reprod Nutr Dev 1986;26:619-31.

11. Patel MS, Srinivasan M. Metabolic programming in the immediate postnatal life. Ann Nutr Metab [Internet] 2011;58 Suppl 2:1828

12. www.who.int [Internet]. Essential Nutrition Actions- Improving maternal, newborn, infant and young child health and nutrition. [Update 2018; Cited 2018 Oct] Available from: http://apps.who.int/iris/bitstream/10665/84409/1/ 9789241505550_eng.pdf

13. Badan Pusat Statistik Kota Bogor. Kota Bogor dalam angka 2017. Available from: http://bappeda.kotabogor.go.id/images/produk

14. de Onis M, Branca F. Childhood stunting: A global perspective. Matern Child Nutr 2016;12:12-26.

15. Addo OY, Stein AD, Fall CH, Gigante DP, Guntupalli AM, Horta BL, et al. Maternal height and child growth patterns. J Pediatr [Internet] 2013;163:549-54.e1. Available from: http://dx.doi.org/10.1016/j.jpeds.2013.02.002

16. Hambidge KM, Mazariegos M, Kindem M, Wright LL, Cristobal-Perez C, Juarez-Garcia L, et al.J Pediatr Gastroenterol Nutr. 2012;54 (1):117-9.

17. Lestari W, Margawati A, Rahfiludin MZ. Faktor Risiko Stunting pada Anak Umur 6-24 bulan di Kecamatan Penanggalan Kota Subulussalam
Provinsi Aceh. J Gizi Indones 2014;3:37-45.

18. Inoue $\mathrm{S}$, Naruse $\mathrm{H}$, Yorifuji $\mathrm{T}$, Kato $\mathrm{T}$, Murakoshi T, Doi H, et al. Association between short maternal height and low birth weight: A hospital-based study in Japan. J Korean Med Sci 2016;31:353-9.

19. Wells JCK, Figueiroa JN, Alves JG. Maternal pelvic dimensions and neonatal size:

Implications for growth plasticity in early life as adaptation. Evol Med Public Heal 2017;2017:191-200.

20. Godfrey KM, Lillycrop K a, Burdge GC, Gluckman PD, Hanson M a. Non-imprinted epigenetics in fetal and postnatal development and growth. NestleNutrInst Work Ser 2013;71:57-63.

21. Parsons TJ, Power C, Manor O. Fetal and early life growth and body mass index from birth to early adulthood in 1958 British cohort: a longitudinal study. BMJ 2001;323:1331-5.

20. Irawati A, Rachmalina R. Indeks massa tubuh ibu pra hamil sebagai faktor risiko pertambahan berat badan ibu hamil di kelurahan Kebon Kelapa and Ciwaringin, Kecamatan Bogor Tengah, Kota Bogor. Jurnal Ekologi Kesehatan. 2013; 12(2):117-127

23. Rogol AD, Hayden GF. Etiologies and Early Diagnosis of Short Stature and Growth Failure in Children and Adolescents. J Pediatr [Internet] 2014;164:S1-14.e6

24. Dewey KG. Reducing stunting by improving maternal, infant and young child nutrition in regions such as South Asia: evidence, challenges and opportunities. Matern Child Nutr [Internet] 2016;12:27-38. Available from: http://doi.wiley.com/10.1111/mcn.12282 